\title{
The Purposive Study of Names
}

\author{
WILLIAM HARDY ALEXANDER
}

\section{$\mathrm{I}_{\mathrm{r}}$}

T was good to see Professor McGartney's name among the contributors to the September, 1953, issue of Names. He has for years entertained and instructed classicists without number in the Classical Journal and the Classical Weekly; it is a great satisfaction to see him include Names within his territory.

The instances that he cites from antiquity of persons who displayed extraordinary powers in the mastering of name-lists are striking. This is, I should think, a very particular phase of memory work, and was applied, as one can see from the persons mentioned, to very particular purposes. Cyrus wanted to make the personal touch count in the handling of his army; to master the muster roll of officers alone was no mean task, although I feel that ancient armies got along with a great many fewer officers, both commissioned and noncommissioned, than we do. The strength of the Roman legion, for example, with its 4,000 to 6,000 men, lay very largely in its sixty centurion N.C.O.'s, among whom the primipilus, the first sergeant of the first century, was really the heart of the legion's life and labors. Professor McCartney reminds us that Julius Caesar, who certainly had a lot of things to think about, knew the names of many of his centurions; he has left us in his Bellum Gallicum tributes to the character and the military virtues of some of these, after mentioning their names specifically. ${ }^{1}$

With Themistocles the object was largely political, although we may be sure that he could address by name all the ship-captains at Salamis, just as Nikias did at the final battle in the harbor at Syracuse. But we must not minimize his achievement in having "by heart," as our fathers put it, the names of all Athenian citizens (males, that is), perhaps 15 ,00o in his time. ${ }^{2}$ I think myself that that is a Herculean feat in any country in any age, but Professor McCartney's fifth note credits James A. Farley with something out- 
running even Themistocles' achievement. Cato the Elder knew names for a like purpose, politics, and Cicero for the same reason.

The Romans, as might be expected, organized the business. No servant of the Big House occupied a more important post than the nomenclator (McGartney, p. 194), so invaluable day by day at the formal receptions given by the nobility to their clients, when he whispered to the master swiftly and accurately the name of each "next up" in the line of guests, or nudged his elbow knowledgefully as they made their way down town to the Forum, indicating promptly and surely that a person of importance was approaching and supplying the name of that precinct leader seen in the near distance, a man who could deliver such and such a number of votes in his century or in his tribe. Seneca gives us pathetic items on aged nomenclatores whose memory for names is failing; the poor fellows try to replace genuine recollection with artful invention, winning, no doubt, glares from the misnamed parties. ${ }^{3}$ The Roman nomenclator was, literally, the master's hired (or rather, purchased) memory, and why not? The master had the means to buy the talent, the nomenclator had the talent worthy to be bought. Seneca also tells us of a rich parvenu who wanted to exhibit an apparent acquaintance with literature at his dinners. He was bad enough in misquoting the Iliad and the Odyssey, but impossible when it came to the lyric poets. Finally, recognizing the facts of the situation, he let out a contract for the training of nine slaves, each of whom would be a specialist in one of the lyricists, ready to pop up and provide the ipsissima verba when Callistus said: "You remember the place where Bacchylides remarks-," or, better yet, not to pop up but to whisper them from his position seated at his owner's feet."

There are undoubtedly great natural memories, but many memories, especially political memories, are the result of deliberate hard work. If Cyrus and Themistocles were masters of the lists with which they are credited, I venture to guess that they worked on the job; we must avoid attributing too keen a memory to Themistocles, for example, on the basis of his telling the professor of Business Mnemonics that what he was really looking for was a professor of Business Oblivescence. As for Agamemnon in the Iliad, things were at a terrible pass among the Greeks with Achilles out of the war, and I fancy that the instructions to Menelaus in preparation 
for the Embassy to Achilles mark the solemnity of the occasion: "Call aloud, wheresoever thou goest, and bid men awake, naming each man by his lineage, and his father's name, and giving them all their due of honor." Those who are interested in names will, of course, have noticed the very great difference between "Please do that for me," and "Bob, you simply must do that for me."

I remember hearing some years ago a story from American politics that fits perfectly into this whole discussion; precise names were never, of course, furnished by the tellers of the tale.

It was a notable fact that in a certain Southern state one of the United States senators possessed-or appeared to do so-a most remarkable memory for names. He was given the same credit that the ancients gave some of their outstanding characters, and very likely in this glorification accorded the Senator the very persons whom Professor McCartney has revived for us from classical antiquity were mentioned illustratively; Southerners were alwaysperhaps still are-good classicists.

Now this Senator always excused himself quite promptly after lunch, saying with a smile: "We public men have to be particular about our digestion and our rest." It came out, however, after the Senator's death, that on going into this or that particular district "politicking," he would take with him a box filled with $3 \times 5$ cards, each one of which carried a voter's name with relevant personal, financial, and political items attached; also in many cases a small picture of the person, sometime a snapshot, sometimes cut from a newspaper. Facts such as married or unmarried were recorded; in the former event children, number, sex, ages, names, and the like.

Thus from the moment when the Senator stepped off the train at this or that town, the work of what seemed an extraordinary memory began. "Why, this is Harry Jones, of course! Harry, how are you? How's that fine wife of yours? A real Southern girl if there ever was one. And those two boys-is Tom thinking of college yet? There'll be something for him in Washington by the time he's through. Just remind me, Harry. And I hope I live long enough to do something for Ted. Then those girls. Kate's the oldest of the three, isn't she? And then there's Julia and Margaret; have I got it straight? Well, I couldn't forget them very well."

"Why, Senator, you surprise me. You certainly have a wonderful memory." "For my friends, Harry, for my friends. It's always easy 
for me to remember friends-God's greatest gift to man! Especially," with a sigh, "in public life." Shall we blame the Senator if a few well applied moments just after lunch the day before or in the course of his train journey had whetted up his "memory"? I wonder what was Themistocles' system; did he keep a few baskets of ostraka (clay tablets) always handy? And after all was the Senator's friendship any the worse for being kept warm by a good business system?

The whole discussion shows that a man's name is always regarded by that man as an important part of himself; is it not the case that in some South Pacific tribes men have two names, one the real name of the man himself, the other for general circulation? And wasn't Romulus, thus earth-named, provided also with the sacred name Quirinus to use when he went up to heaven in a chariot of fire? Well, isn't it true among ourselves that one feels pleased, even flattered, if a public man, or indeed just some old acquaintance he hasn't seen for years, promptly hails him by name or, even better, a nickname?

Believe me, there is a certain special something in names which it is worth struggling to master and to conserve, and it is a matter of genuine satisfaction that among ourselves a body of people and a journal are now committed to the recording and the study of the labels, frequently of the greatest interest, by which men and places get identified.

\section{NOTES}

${ }^{1}$ De Bello Gallico 5.35,6-7 (Titus Balventius and Quintus Lucanius); 5.37.5 (Lucius Petrosidius).

${ }^{2}$ It is pretty well agreed that the male citizens of Athens at the height of her power under Pericles numbered no more than 25,000 or 30,000 at most.

${ }^{3}$ Epistulae Morales 27.5: "no antique nomenclator who does not report the names of guests but confers names upon them." Cf. also De Beneficiis 1.3.10: "Nerve takes the place of memory with the nomenclator, and where he cannot recall a name, he confers one."

${ }^{4}$ Epistulae Morales 27.6: "There is no reason for your being surprised at his paying a fancy figure [for these slaves]. He didn't find them ready-made; he let out a contract to have them made." 